\title{
Inflammation - Cause or Consequence of Heart Failure or Both?
}

\author{
Sophie Van Linthout ${ }^{1}$ • Carsten Tschöpe ${ }^{1,2}$
}

Published online: 30 June 2017

(C) The Author(s) 2017. This article is an open access publication

\begin{abstract}
Purpose of Review With the intention to summarize the currently available evidence on the pathophysiological relevance of inflammation in heart failure, this review addresses the question whether inflammation is a cause or consequence of heart failure, or both.

Recent Findings This review discusses the diversity (sterile, para-inflammation, chronic inflammation) and sources of inflammation and gives an overview of how inflammation (local versus systemic) can trigger heart failure. On the other hand, the review is outlined how heart failure-associated wall stress and signals released by stressed, malfunctioning, or dead cells (DAMPs: e.g., mitochondrial DNA, ATP, S100A8, matricellular proteins) induce cardiac sterile inflammation and how heart failure provokes inflammation in various peripheral tissues in a direct (inflammatory) and indirect (hemodynamic) manner. The crosstalk between the heart and peripheral organs (bone marrow, spleen, gut, adipose tissue) is outlined and the importance of neurohormonal mechanisms including the renin angiotensin
\end{abstract}

This article is part of the Topical Collection on Comorbidities of Heart Failure

Sophie Van Linthout

sophie.van-linthout@charite.de

Carsten Tschöpe

carsten.tschoepe@charite.de

1 Berlin-Brandenburg Center for Regenerative Therapies, Charité - Universitätsmedizin Berlin, Freie Universität Berlin, Humboldt-Universität zu Berlin, and Berlin Institute of Health, Berlin, Germany

2 Department of Cardiology, Campus Virchow Klinikum, Charité - Universitätsmedizin Berlin, Freie Universität Berlin, Humboldt-Universität zu Berlin, and Berlin Institute of Health, Berlin, Germany aldosteron system and the $\beta$-adrenergic nervous system in inflammation and heart failure is discussed.

Summary Inflammation and heart failure are strongly interconnected and mutually reinforce each other. This indicates the difficulty to counteract inflammation and heart failure once this chronic vicious circle has started and points out the need to control the inflammatory process at an early stage avoiding chronic inflammation and heart failure. The diversity of inflammation further addresses the need for a tailored characterization of inflammation enabling differentiation of inflammation and subsequent target-specific strategies. It is expected that the characterization of the systemic and/or cardiac immune profile will be part of precision medicine in the future of cardiology.

Keywords Heart failure · Sterile inflammation ·

Para-inflammation · Cardiosplenic axis · Monocytopoiesis . ß-adrenergic signaling

$\begin{array}{ll}\text { Abbreviations } \\ \text { ACS } & \text { Acute coronary syndrome } \\ \text { Ang II } & \text { Angiotensin II } \\ \text { ANP } & \text { Atrial natriuretic peptide } \\ \text { AT1R } & \text { Angiotensin II type 1 receptor } \\ \text { BNP } & \text { Brain natriuretic peptide } \\ \text { DAMP } & \text { Danger-associated molecular pattern } \\ \text { ECM } & \text { Extracellular matrix } \\ \text { HF } & \text { Heart failure } \\ \text { HFmEF } & \text { Heart failure with mid-range ejection fraction } \\ \text { HFpEF } & \text { Heart failure with preserved ejection fraction } \\ \text { HFrEF } & \text { Heart failure with reduced ejection fraction } \\ \text { LOX } & \text { Lysyloxidase } \\ \text { LPS } & \text { Lipopolysaccharide } \\ \text { LV } & \text { Left ventricular } \\ \text { M } \Phi & \text { Macrophage }\end{array}$




$\begin{array}{ll}\text { MI } & \text { Myocardial infarction } \\ \text { MSC } & \text { Mesenchymal stromal cell } \\ \text { NADPH } & \text { Nicotinamide adenine dinucleotide phosphate } \\ \text { NLRP3 } & \begin{array}{l}\text { Nucleotide-binding oligomerization domain-like } \\ \text { receptor with a pyrin domain 3 }\end{array} \\ \text { NOX } & \text { NADPH oxidase } \\ \text { PAMP } & \text { Pathogen-associated molecular pattern } \\ \text { PRR } & \text { Pattern recognition receptors } \\ \text { RAGE } & \text { Receptor for advanced glycation endproducts } \\ \text { RAAS } & \text { Renin angiotensin aldosteron system } \\ \text { ROS } & \text { Reactive oxygen species } \\ \text { SIRS } & \text { Systemic inflammatory response syndrome } \\ \text { TLR } & \text { Toll-like receptor } \\ \text { TNF } & \text { Tumor necrosis factor } \\ \text { TGF } & \text { Transforming growth factor }\end{array}$

\section{Introduction}

Heart failure (HF) is one of the most common disorders in Western societies, and its prevalence is still rising. Approximately 50\% of all HF patients suffer from HF with reduced ejection fraction (HFrEF; typically considered as EF $<40 \%$ ), whereas the other half suffers from HF with preserved ejection fraction (HFpEF; $\geq E F 50$ ). Patients with a left ventricular ejection fraction in the range of 40-49\% represent a "gray area," which is newly defined as HF with mid-range ejection fraction (HFmEF) [1]. The HF epidemic can be explained by the paradox of clinical success, leading to a decrease in mortality due to myocardial infarction (MI) and consequential raise in surviving HF patients, as well as by the increasing prevalence of diabetes mellitus and obesity, which are besides hypertension and COPD, the main comorbidities associated with HFpEF [2].

Our understanding regarding the development and progression of HF has changed over the last decades. Physicians have traditionally considered HF to be a hemodynamic disorder. The inability of the so-called hemodynamic hypothesis to explain the progression of $\mathrm{HF}$ and the evidence that activation of the sympathetic nervous system and renin angiotensin aldosteron system (RAAS) exerts a direct deleterious effect on the heart that is independent of the hemodynamic actions of these endogenous mechanisms has then given rise to the notion that HF may progress as a result of the overexpression of neurohormones (neurohormonal hypothesis) [3]. In the 1990s, it has become apparent that in addition to neurohormones, cytokines play an important role in the pathogenesis of HF (cytokine hypothesis) [4]. The last decade, inflammation has more and more been recognized to play an important role in the pathogenesis of both main forms of HF $[5,6 \bullet, 7 \bullet \bullet, 8]$ and as a consequence, to be an important therapeutic target for the treatment of HF $[9,10]$. Common to both forms of HF is the correlation between elevated serum concentrations of pro- inflammatory cytokines and adverse clinical outcomes [11-13]. However, how inflammation contributes to the pathogenesis of both main forms of HF is different. For HFpEF, a novel paradigm was postulated which identifies a systemic proinflammatory state induced by comorbidities as the origin of microvascular endothelial cell inflammation, which triggers HFpEF-specific, i.e., concentric, cardiac remodeling, and dysfunction [6•]. With respect to HFrEF, cardiomyocyte damage directly induced by, e.g., myocardial infection or ischemia underlies inflammation triggering eccentric cardiac remodeling and dysfunction. Besides the different causes of inflammation, inflammation itself is diverse and complex, which might explain the disappointing results of anti-inflammatory strategies so far $[14,15]$. Indeed, it is more and more recognized that further insights into this diversity and complexity depending on the specific cardiac disorder are required in view of finding target-specific therapies. With the intention to summarize the currently available evidence on the pathophysiological relevance of inflammation in HF, this review addresses the question whether inflammation is a cause or consequence of $\mathrm{HF}$, or both. In general, this question reflects whether inflammation can damage tissue or tissue damage can trigger inflammation, or both. To be able to answer this question, it is first of all necessary to know how inflammation is defined. Therefore, the inflammatory response, sterile inflammation, para-inflammation, and chronic inflammation are briefly discussed. Next, different sources of inflammation and their contribution to HF are outlined, followed by how HF can induce inflammation.

\section{Inflammation}

The first century Roman doctor Cornelius Celsus described the four cardinal signs of inflammation, rubor et tumor cum calore et dolore (redness and swelling with heat and pain) [16]. Only in 1858, the fifth cardinal sign, functio laesa (disturbance of function), was added by Rudolph Virchow [17]. In contrast to the four cardinal signs, which only apply to acute inflammation accompanying wounds and infections, functio laesa is the only universal sign of inflammation [16]. A typical inflammatory response consists of four components: (1) the inflammatory inducers, classified in exogenous (microbial inducers including pathogen-associated molecular patterns (PAMPs), virulence factors, and non-microbial inducers: allergens, toxic compounds, irritants) and endogenous inducers (danger-associated molecular patterns (DAMPs): cell-, tissue-, plasma-, extracellular matrix (ECM)-derived products); (2) the sensors that detect them including pattern recognition receptors (PRRs) or other sensors like the nucleotide-binding oligomerization domain-like receptor with a pyrin domain 3 (NLRP3) inflammasome; (3) the inflammatory mediators induced by the sensors (vasoactive amines and peptides, fragments of complement components, lipid mediators, proteolytic enzymes, 
chemokines, and cytokines); and (4) the target tissues that are affected by the inflammatory mediators [16]. With respect to mediators, this review particularly discusses the relevance of cytokines in HF.

\section{Sterile Inflammation}

If inflammation occurs in the absence of infection, one speaks of sterile inflammation. Post-ischemic or toxic necrosis, massive trauma, hemorrhage, and resuscitation can each trigger an inflammatory response. Molecules released from dying cells, altered host cell products (breakdown products of the ECM, oxidized lipoproteins), and abnormally released host cell products (e.g., heat shock proteins) are involved. Inflammatory responses induced by sterile stimuli are very similar to responses during infection, including the recruitment of neutrophils and

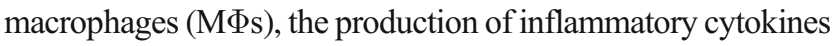
and chemokines, and the induction of T cell-mediated adaptive immune responses [18]. Sterile endogenous stimuli trigger inflammation via (1) activation of PRRs by mechanisms similar to those used by microorganisms and PAMPs, but weaker and delayed as shown for a sterile signal-induced macrophage NLRP3 inflammasome response relative to microbial signals [19]; (2) release of intracellular cytokines which activate common pathways downstream PRRs; and (3) activation of receptors which are not typically associated with microbial recognition like the receptor for advanced glycation endproducts (RAGE) and CD36 [18].

\section{Para-inflammation}

This response is characterized by no massive tissue injury and a limited inflammatory activation. Therefore, it is termed parainflammation derived from the Greek prefix $\pi \alpha \rho \alpha /$ para for near [20]. This response relies mainly on tissue-resident M $\Phi$ s. If tissue malfunction is present for a sustained period, parainflammation can become chronic [20]. This form of inflammation often accompanies obesity, the metabolic syndrome, type 2 diabetes, atherosclerosis, aging, and other chronic inflammatory conditions that are associated with modern human diseases. Para-inflammation is consequently also called "lowgrade" chronic inflammation and in case of metabolismtriggered inflammation, "meta-inflammation" [21]. Environmental factors including caloric excess, intake of processed foods, use of antibiotics, and physical inactivity, common to Western lifestyle [22], as well as endocrine disruptors and early life influences (maternal nutrition, placental function) underlie para-inflammation.

\section{Chronic Inflammation}

Chronic inflammation can be caused by persistence of the inflammatory trigger, which disables an appropriate induction of the resolution phase and can occur when there is a positive feedback loop between inflammation and the pathological process it accompanies. Obesity for example can lead to inflammation, whereas chronic inflammation can induce obesity-associated diabetes in part by inducing insulin resistance [21]. With respect to pathophysiological processes in the heart, there is accumulating evidence that inflammationtriggered myofibroblasts are capable of inducing the inflammatory response by their own via (1) expressing chemokines, attracting immune cells to the heart, (2) inducing adhesion molecules on the endothelium, (3) stimulating monocytes to express gelatinases, facilitating transmigration of immune cells through the basolateral membrane [23, 24], and (4) NLRP3 inflammasome activity and IL-1ß release [25]. In this manner, a vicious circle is induced supporting chronic inflammation in the heart [24].

\section{Inflammation Causes Heart Failure}

Inflammation triggers $\mathrm{HF}$ in its different aspects, ranging from its impact on the pathogenesis of HF including HFunderlying comorbidities like diabetes and obesity [26, 27], and on pathological substrates underlying heart disease like endothelial dysfunction [28-31] and atherosclerosis [32], to its influence on the progression and outcome of acute coronary syndrome (ACS) [33] and HF [34]. Blood monocyte levels [35] and splenic activity [36] can predict cardiovascular events in patients, C-reactive protein levels are higher in patients with recurrent events [37], and cardiac inflammation is a predictor for a negative outcome in patients with dilated cardiomyopathy [34]. Inflammatory cytokine (TNF- $\alpha$, IL13 , IL-6) levels are increased in HF patients [38]. There is a correlation between serum levels of TNF- $\alpha$ and the severity of the disease [38], and cytokines and cytokine receptors are independent predictors of mortality in patients with advanced HF [39]. The relevance of inflammation in HF follows from experimental studies in animal models of MI, diabetic cardiomyopathy, pressure overload, and myocarditis using knockout [40-42], or transgenic [43] mice, or mice treated with anti-inflammatory or immunomodulatory strategies, including antibodies (e.g., TNF- $\alpha$ antibody [44], IL-6R antibody [45]), inhibitors (IL-1 converting enzyme inhibitor [46]), agonists/antagonists of cytokines/chemokines (IL-2 agonist [47], CCR2 siRNA [48]), statins [49], HDL-raising strategies [29-31, 50, 51], cell therapies including mesenchymal stromal cells (MSC) [52-54], and cardiac-derived stromal cells $[55,56]$. The inflammation-induced cardiac pathophysiological mechanisms underlying HF will next shortly be discussed followed by evidence of high-grade and low-grade systemic inflammation affecting HF.

At the latest, since the cytokine hypothesis from the 1990s [4], it is well established that cytokines exert detrimental effects on the heart. Cytokines like TNF- $\alpha$ and IL-1 $\beta$ 
downregulate the expression of $\mathrm{Ca}^{2+}$-regulating genes including sarcoplasmic reticulum $\mathrm{Ca}^{2+}$ ATPase [57] and $\mathrm{Ca}^{2+}{ }^{2+}$-release channel [58], leading to a direct negative inotropic effect as a direct result of alterations in intracellular $\mathrm{Ca}^{2+}$ homeostasis in the adult cardiac myocyte [59]. Abnormalities in sarcoplasmic reticulum $\mathrm{Ca}^{2+}$ release promote on their turn eccentric myocardial remodeling (eccentric hypertrophy, substantial fibrosis, ventricular dilation) and pump failure, ultimately resulting in overt HF, in response to pressure overload [60]. This points out that inflammation-triggered $\mathrm{Ca}^{2+}$ dysbalance can contribute to cardiac remodeling, leading to a vicious circle [61]. TNF- $\alpha$ and IL- $1 \beta$ further promote cardiomyocyte hypertrophy [62] and the cytokine IL-6 has been demonstrated to increase cardiomyocyte stiffness via reducing the phosphorylation of titin [45]. TNF- $\alpha$ also triggers cardiomyocyte apoptosis [63] and IL-1ß cardiomyocyte pyroptosis [64].

On cardiac fibroblasts, TNF- $\alpha$ and IL- $1 \beta$ upregulate angiotensin II type 1 receptors (AT1R) and they induce AT1R density in the post-MI heart [65]. The upregulation in AT1 receptor expression enhances the angiotensin (Ang) II-mediated cardiac fibroblast responses that favor fibrosis [66]. TNF- $\alpha$ and IL- $1 \beta$ neutralization ameliorates Ang II-induced cardiac damage, further supporting synergistic actions of Ang II and TNF- $\alpha /$ IL-1ß [67]. TNF- $\alpha$ also induces TGF- $\beta$ [68] and increases the expression of cardiac fibroblast lysyl oxidase (LOX) expression through TGF- $\beta$ and PI3Kinase signaling pathways [69]. LOX belongs to a family of enzymes [70], including LOX-like 2, responsible for the crosslinking of ECM proteins, including collagen types I and III. The relevance of LOX-like 2 as therapeutic target of cardiac fibrosis and as biomarker for HF has recently been demonstrated [71]. TGF- $\beta$ induces fibroblasts to transdifferentiate into active myofibroblasts. Those cells are not only active in producing collagens but they also act as inflammatory support cells via their capacity to express chemokines, to release factors inducing adhesion molecules on endothelial cells, and via their ability to stimulate monocytes to express gelatinases facilitating degradation of the basolateral membrane and subsequent infiltration of immune cells in the heart $[23,24]$ and their capacity to modulate the $M \Phi M 1 / M 2$ balance [72]. Furthermore, activated fibroblasts promote cardiomyocyte hypertrophy and dysfunction via the release of pro-fibrotic factors, such as TGF- $\beta 1$, Ang II, and fibroblast growth factor [73, 74].

On (cardiac) endothelial cells, pro-inflammatory cytokines induce adhesion molecule expression [75] and promote subsequent adhesion of immune cells to the endothelium [76] and transendothelial migration [77]. They induce apoptosis in cardiac endothelial cells [78] and oxygen-centered free radicals, which stimulate the elaboration of plasminogen activator inhibitor- 1 and collagen by cardiac microvascular endothelial cells. Accordingly, microvascularly mediated inhibition of fibrinolysis may predispose to the persistence of microvascular thrombi, thereby contributing to impaired microcirculatory function, the no-reflow phenomenon, and cardiac dysfunction after ischemia and reperfusion [79]. TGF- $\beta$ and Ang II induce endothelial-to-mesenchymal transition, the transition from an endothelial to a fibroblast phenotype [29], a phenomenon, which has been shown to contribute to cardiac fibrosis in a landmark study by Zeisberg et al. [80]. Recently, it has been shown that TNF- $\alpha$-induced endothelial natriuretic peptide/ guanylate cyclase $\mathrm{A} / \mathrm{cGMP} /$ phosphodiesterase 2 signaling impairs endothelial barrier functions and enhances myocardial inflammatory infiltration in the early phase after an acute infarction [81].

Inflammatory cytokines further promote structural and electrical atrial remodeling via impairment of gap junctions by changes in connexins and via inducing intracellular $\mathrm{Ca}^{2+}$ handling abnormalities and atrial fibroblast activation, leading to impaired atrial conduction [82].

\section{Sources of Inflammation}

The cytokines inducing cardiac remodeling and dysfunction can originate from the heart itself (cardiokines) [83], produced by cardiomyocytes [84], cardiac endothelial cells [85], cardiac fibroblasts [25], cardiac tissue M $\Phi \mathrm{s}$ [86], and cardiac infiltrated immune cells, or can be of extra-cardiac tissues including adipose tissue, gut, and lymphoid organs. Failing human myocardium expresses abundant quantities of TNF- $\alpha$ [11]. Cardiomyocytes have TNF- $\alpha$ receptors on their surfaces [87] and these receptors appear to be released into the circulation during HF [11]. The importance of TNF- $\alpha$ in HF has experimentally been shown in transgenic mice where chronic cardiomyocyte overexpression of TNF- $\alpha$ resulted in the development of dilated cardiomyopathy with ventricular hypertrophy, ventricular dilatation, interstitial infiltrates, interstitial fibrosis, rare myocyte apoptosis, diminished ejection fraction, attenuation of $\beta_{1}$-adrenergic responsiveness, and expression of atrial natriuretic peptide (ANP) in the ventricle [43].

NLRP3 is considered necessary for initiating a profound sterile inflammatory response. Cardiac endothelial cells [85] and cardiac fibroblasts [25] are both important sources of IL$1 \mathrm{~B}$, one of the endproducts of NLRP3 inflammasome activity. By ischemia/reperfusion injury, the NLRP3 inflammasome is activated as indicated by increased NLRP3 expression, caspase- 1 activity, and increased IL- $1 \beta$ and IL-18 production. Simulated ischemia/reperfusion-stimulated NLRP3 inflammasome activation in cardiac microvascular endothelial cells, but not in cardiomyocytes [85]. In another study, a marked increase in NLRP3, IL-1ß, and IL-18 mRNA expression was found in the left ventricle after MI, primarily located to myocardial fibroblasts [25]. The relevance of NLRP3 inflammasome activity in HF follows from studies demonstrating that when hearts were isolated from NLRP3deficient mice, perfused and subjected to global ischemia and reperfusion, a marked improvement of cardiac function 
and reduction of hypoxic damage was found compared with wild-type hearts [25], whereas Toldo et al. [88] showed that the formation of the inflammasome in acute myocarditis is predictive for the NYHA class and outcome.

In the healthy mouse heart, $\approx 6$ to $8 \%$ of non-cardiomyocytes are resident $M \Phi s$ [86], a number comparable to the frequency of

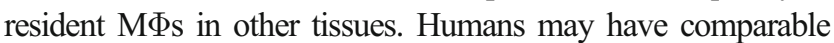
numbers, after $M I$, the $M \Phi$ numbers increase in the heart through the combined effects of massive recruitment of circulating monocytes (that become macrophages in tissues) and local selfrenewal of tissue-resident $M \Phi s$ [89]. M $\Phi$ s are traditionally classified in inflammatory $\mathrm{M} \Phi \mathrm{s}$, often referred to as classical or M1 $\mathrm{M} \Phi \mathrm{s}$, secreting pro-inflammatory cytokines as IL-6, TNF- $\alpha$, IL$1 \beta$, IL-12, and IL-23, and heal/growth-promoting M $\Phi$ s, commonly called alternatively activated or $\mathrm{M} 2 \mathrm{M} \Phi \mathrm{s}$, expressing antiinflammatory IL-10 and TGF- $ß$ [90]. M1 and M2 M $\Phi$ s usually appear in sequence upon MI, i.e., in the inflammatory versus the wound healing phase, respectively, whereas also mixed M1/M2 phenotypes can be found [91]. The relevance of cardiac M1 toward M2 M $\Phi$ phenotype transition for the resolution of inflammation and tissue repair post MI has recently been shown by Courties et al. (2014) [92] who demonstrated that in vivo silencing of the transcription factor IRF5, which is involved in inflammatory M1 M $\Phi$ polarization, supported resolution of inflammation, accelerated infarct healing, and attenuated development of post-MI HF.

Besides endogenous cardiac cells, infiltrated inflammatory cells are responsible for local cardiac cytokine expression. Those immune cells originate from lymphoid organs as the spleen and the bone marrow [93]. Pre-clinical studies have demonstrated that after MI in mice, monocyte progenitor cells depart bone marrow niches, which results in amplified extramedullary monocytopoiesis [36, 94]. The observation of the activation of splenic monocytes and the migration of pro-inflammatory monocytes from the spleen to the heart in animal models of MI [95] and chronic HF [96] have given rise to the concept of a cardiosplenic axis. This recruitment from the spleen depends in part on Ang II, an observation that may underlie the beneficial effect upon angiotensin converting enzyme inhibition on remodeling in the infarcted myocardium [97]. In accordance with the cardiosplenic axis and the immunomodulatory properties of MSC $[52,53]$, we recently demonstrated that intravenous MSC application in CVB3-induced myocarditis modulates monocytes trafficking to the heart. They reduced blood and cardiac pro-inflammatory monocytes and retained those in the spleen, whereas MSC increased antiinflammatory monocytes in the spleen, blood, and heart [54].

Evidence for the existence of a cardiosplenic axis is further supported by observations in human post-mortem tissue specimens of the heart, spleen, and bone marrow demonstrating a unique spatio-temporal pattern of monocyte accumulation in the human myocardium following acute MI that coincides with a marked depletion of monocytes from the spleen, suggesting that the human spleen contains an important reservoir function for monocytes [98]. Patients with acute MI exhibit an increased inflammatory status/metabolic activity of the spleen, bone marrow, and carotid artery. This has been demonstrated via ${ }^{18} \mathrm{~F}$-fluorodeoxyglucose $\left({ }^{18} \mathrm{~F}\right.$-FDG) positron emission tomography, which evaluates the metabolic activity based on the finding that activated inflammatory cells express high levels of glucose transporters and accumulate ${ }^{18} \mathrm{~F}-\mathrm{FDG}$ [93]. Emami et al. [36] further demonstrated that after ACS, the gene expression of circulating pro-inflammatory monocytes (i.e., CD36, S100A9, IL-1ß, and TLR4) was more closely associated with the metabolic activity of the spleen than it was for the bone marrow. They further observed that the metabolic activity of the spleen independently predicted the risk of subsequent cardiovascular disease events. In patients with acute MI, high monocyte blood levels, which are a strong predictor of mortality, correlate inversely with the ejection fraction [99]. Collectively, the abovementioned findings provide evidence of a cardiosplenic axis in humans similar to that shown in pre-clinical studies [36].

\section{High-Grade Systemic Inflammation}

Evidence from chronic immune-mediated diseases like rheumatoid arthritis associated with persistent high-grade systemic inflammation demonstrates the impact of systemic inflammation on HF. Patients with rheumatoid arthritis have a 1.5-2.0 times higher prevalence of ischemic heart disease and congestive HF compared to the general population [100]. Furthermore, atherosclerosis progresses most rapidly during the first 6 years after rheumatoid arthritis diagnosis [101], indicating how enduring systemic inflammation plays a major role in accelerating heart disease development in these patients. Systemic inflammation can induce autonomic nervous system dysfunction. Inflammatory cytokines increase the sympathetic outflow by targeting the autonomic centers in the brain, which in turn inhibits cytokine production and immune-inflammatory activation by stimulating the $\beta 2$ adrenoreceptors in circulating lympho-monocytes [102]. This self-controlling loop, so-called inflammatory reflex [103], and in this context, sympathetic activation, consequently damps excessive immune-inflammatory activation, but also affects the heart, potentially favoring the onset of arrhythmias [104] and HF. In extreme cases of inflammation as systemic inflammatory response syndrome (SIRS), or sepsis, the hemodynamic changes due to hypotension may directly underlie the induction of the neuroendocrine system, independent of the inflammatory response.

\section{Low-Grade Systemic Inflammation}

Obesity is characterized by a low-grade systemic chronic inflammatory state [26]. The multisystem effects of obesity are 
linked to an imbalance in homeostatic and pro-inflammatory immune responses. A major player in systemic low-grade chronic inflammation in obesity is the increased numbers of adipose tissue pro-inflammatory $\mathrm{M} \Phi \mathrm{s}$ and deregulated production and function of adipose tissue hormones and adipokines including adiponectin [105], which strongly contributes to the initiation and exacerbation of type 2 diabetes [106]. Over time, ectopic lipid accumulation in the muscle, liver, and blood vessels activates tissue leukocytes, contributes to organ-specific disease, and exacerbates systemic insulin resistance. Cellular- and cytokine-mediated inflammation in the pancreatic islets accelerates the progression toward diabetes [26]. The obesity-associated alterations in adipokine expression (adiponectin $\downarrow$, TNF- $\alpha \uparrow$ ) also contribute to HFpEF [106]. Indeed, adiponectin deficiency known to exacerbate the development of obesity-related hypertension [107], adverse cardiac remodeling [108] in ischemia-reperfusion injury [109], and MI [110], increased the propensity to develop diastolic $\mathrm{HF}$ and diastolic dysfunction in a murine model of $\mathrm{HFpEF} /$ diastolic HF [111]. In contrast, adiponectin overexpression in aldosterone-infused mice ameliorated left ventricular (LV) hypertrophy, diastolic dysfunction, lung congestion, and myocardial oxidative stress without affecting the blood pressure and LV ejection fraction [112].

Diabetes and obesity both induce hematopoiesis and myelopoiesis. Hyperglycemia promotes myelopoiesis via interaction of neutrophil-derived S100A8/A9 with RAGE on hematopoietic stem cells [113]. S100A8/A9-induced TLR4/MyD88 and NLRP3 inflammasome-dependent IL-1ß production in adipose tissue $M \Phi$ s interacts with the IL-1 receptor on bone marrow myeloid progenitors to stimulate the production of monocytes and neutrophils. These studies uncover a positive feedback loop between adipose tissue $M \Phi s$ and bone marrow myeloid progenitors and suggest that inhibition of TLR4 ligands or the NLRP3-IL-1ß signaling axis could reduce adipose tissue inflammation and insulin resistance in obesity [114].

In line with the HFpEF paradigm postulated by Paulus and Tschöpe [6 ${ }^{\bullet}$, it has been demonstrated that the systemic, lowgrade inflammation of metabolic risk contributes to diastolic LV dysfunction and HFpEF through coronary microvascular endothelial activation, which alters paracrine signaling to cardiomyocytes and predisposes them to hypertrophy and high diastolic stiffness $[115,116]$. In detail, the authors showed upregulated E-selectin and intercellular adhesion molecule-1 expression levels, increased NADPH oxidase (NOX) 2 expression in M $\Phi$ s and endothelial cells but not in cardiomyocytes, and uncoupling of endothelial nitric oxide synthase, which was associated with reduced myocardial nitrite/nitrate concentration, cGMP content, and protein kinase $\mathrm{G}$ activity in the myocardium of $\mathrm{HFpEF}$ patients and ZSF1-HFpEF rats. The ZSF1-HFpEF rats are characterized by titin hypophosphorylation and cardiomyocyte stiffness and do not exhibit cardiac fibrosis [116], the other main contributor to cardiac diastolic dysfunction [5, 117, 118]. Murdoch and coworkers [119] demonstrated how Ang IIinduced endothelial NOX 2 activation had profound profibrotic effects in the heart in vivo that lead to a diastolic dysfunction phenotype. Endothelial NOX 2 had proinflammatory effects and enhanced endothelial-tomesenchymal transition, which might be an important mechanism underlying cardiac fibrosis and diastolic dysfunction during increased renin-angiotensin activation. A positive correlation between cardiac collagen, the amount of inflammatory cells, and diastolic dysfunction evident in HFpEF patients further suggests a direct influence of inflammation on fibrosis contributing to diastolic dysfunction [5].

Many studies have indicated that an overactive RAAS, excess oxidative stress, and excess inflammation in the brain cause sympathoexcitation in HF [120]. Partial silencing of brain TLR4 via intracerebroventricular injection of TLR4 siRNA causes sympathoinhibition with the prevention of left ventricular remodeling in MI-induced HF through the reduction of brain pro-inflammatory cytokines [120]. Kishi [121] recently demonstrated that systemic infusion of Ang II directly affects brain AT1R with sympathoexcitation and LV diastolic dysfunction. Furthermore, they demonstrated that targeted deletion of AT1R in astrocytes strikingly improved survival with prevention of LV remodeling and sympathoinhibition in MI-induced HF. Based on these results, the authors propose a novel concept that the brain works as a central processing unit integrating neural and hormonal input, and that the disruption of dynamic circulatory homeostasis mediated by the brain causes HF.

\section{Heart Failure Causes Inflammation}

HF is a clinical diagnosis secondary to either LV systolic or diastolic dysfunction leading to insufficient oxygen and nutrient supply to peripheral organs. HF may underlie different etiologies ranging from ischemic heart disease, valve dysfunction, hypertension, metabolic syndrome, and genetic cardiomyopathies to inflammatory cardiomyopathy. HF induces sterile inflammation in the heart itself triggered by wall stress and signals released by stressed, malfunctioning, or dead cells secondary to $\mathrm{HF}$ and induces inflammation in various peripheral tissues in a direct (inflammatory) [122] and indirect (hemodynamic) manner (Fig. 1). Cardiac cells release regulatory peptides, cardiokines, in response to changes in the cardiac environment. These cardiokines affect the heart (see supra) and also have physiological and pathological roles in organs distal from the heart, such as the spleen, bone marrow, adipose tissue, and muscle, affecting cell death, growth, fibrosis, remodeling, metabolism, and inflammation [122, 123]. 


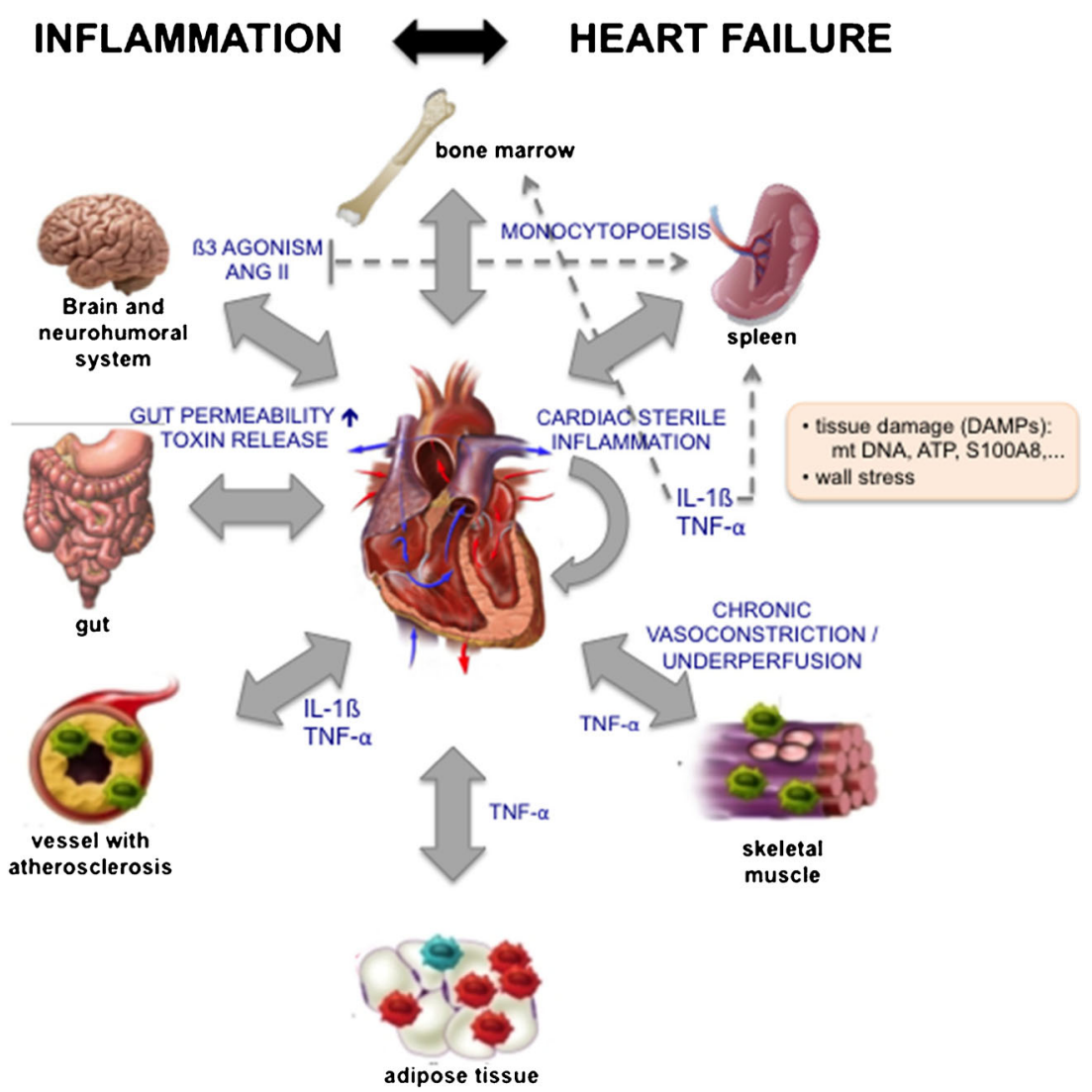

Fig. 1 Inflammation and heart failure reciprocally trigger each other. Heart failure (HF) provokes sterile inflammation in the heart itself triggered by wall stress and signals released by stressed, malfunctioning, or dead cells secondary to HF (DAMPs: e.g., mitochondrial (mt) DNA, ATP, matricellular proteins). The released cardiac cytokines and other inflammatory mediators not only affect the heart but also different organs. IL-1ß induces monocytopoiesis via increasing hematopoietic stem cell proliferation in the bone marrow and monocyte proliferation in the spleen. Cytokines particularly, TNF- $\alpha$, unleashes inflammation in the skeletal muscle and adipose tissue and accelerate atherogenesis. Furthermore, several neurohormonal mechanisms (renin angiotensin aldosteron system (RAAS) and Badrenergic nervous system) that become activated in HF to try and sustain cardiac output in the face of decompensating function also affect inflammation in different organs. B3 agonism and Ang II induce

\section{Heart Failure Provokes Cardiac Inflammation}

Wall stress increases in the failing heart, exposing all cells to increased biomechanical strain. Mechano-sensitive adhesion proteins, including integrins and cadherins, transduce mechanical signals between cells and their microenvironment and can stimulate cellular responses including cell growth, differentiation, and inflammation [124]. TNF- $\alpha$, IL-6, IL-18, and ANP can be induced in stretched myocytes and in hemodynamic-overloaded myocardium [125]. Cyclic stretch enhances the expression of TLR4 in cultured cardiomyocytes via p38 MAP kinase [126], which is known to mediate inflammatory cytokine induction in cardiomyocytes. Cardiac fibroblasts are activated by mechanical stretch mimicking cardiac monocytopoiesis in the spleen. As a consequence of chronic vasoconstriction and underperfusion, inflammation is induced in the skeletal muscle. HF-associated decreased cardiac output and redistribution of systemic circulation can further also lead to a decrease in intestinal perfusion and mucosal ischemia and ultimately, a disrupted intestinal mucosa. This disruption can in turn lead to increased gut permeability and subsequent enhanced translocation of bacteria and bacterial toxins in the blood, which can contribute to systemic inflammation. Systemic inflammation, high-grade (e.g., rheumatoid arthritis) and low-grade (e.g., obesity), and cardiac inflammation induce HF involving different pathophysiological mechanisms. Inflammation triggers cardiomyocyte apoptosis, hypertrophy, stiffness, myofibroblast differentiation, collagen production, endothelial dysfunction, endothelial-to-mesenchymal transition, and subsequent cardiac remodeling and left ventricular dysfunction

dilation in heart failure. Upon stretching, they not only produce more ECM but also upregulate chemokine production and trigger typical inflammatory pathways. Cell culture supernatant of stretched fibroblasts activates inflammatory cells and induces further recruitment of monocytes by allowing transendothelial migration into the cardiac tissue [23]. Furthermore, the mechanical stretch of cardiac fibroblasts, rather than of cardiomyocytes, leads to the release of IL- $1 \beta$ [127], which induces leukopoiesis in the bone marrow and at the extramedullary sites [128].

Wall shear stress on endothelial cells plays an important role in blood vessel physiology and pathology. In regions where undisturbed wall shear stress dominates, endothelial cells are healthy, whereas regions with disturbed wall shear 
stress have endothelial cells with a pro-inflammatory, prooxidative stress phenotype and represent sites where atherosclerosis preferentially develops [129]. Despite substantial evidence for the central role of hemodynamic shear stress in the functional integrity of vascular endothelial cells, hemodynamic and molecular regulation of the endocardial endothelium lining the heart chambers remains understudied [130]. A recent study by McCormick et al. [130] demonstrated spatiotemporal wall shear stress values in defined regions of the left ventricle linking local hemodynamics to regional heterogeneity in endocardial gene expression. However, the spatial regulation of inflammation in cardiac endothelial cells in response to shear stress requires further investigation. M $\Phi$ s respond to strain by inflammatory activation, including increased expression of TNF- $\alpha$, IL-8, IL-6, and MMP-9 [131] and increased expression of scavenger receptors [132]. These phenomena could be of importance in hypertension, which exposes arterial $M \Phi s$ to increased mechanical forces [132]. A recent study of Sager et al. [89] demonstrated that the mechanical strain of primary murine and human $M \Phi$ cultures promoted a cell cycle entry, suggesting that the increased wall tension in post-MI HF stimulates local M $\Phi$ proliferation.

Besides increases in wall stress, HF is associated with cell death, oxidative stress (ROS), hypoxia, and ECM remodeling. TLRs and RAGE are important PRRs for the recognition of endogenous DAMPS including the intracellular S100 proteins, heat shock protein, HMGB1, matricellular proteins, and mitochondrial DNA, released by the heart during HF. Stimulation of TLRs in cardiomyocytes initiates a NF-kB-dependent inflammatory response [133]. Extracellular mitochondrial DNA activates NF-kB via TLR9 in cardiomyocytes [134], and heat shock protein 60 induces inflammation through activating and upregulating TLRs in cardiomyocytes [135]. The alarmin S100A1 is released from ischemic cardiomyocytes and signals myocardial damage via TLR4 [136], whereas the alarmin S100A8/A9 aggravates post-ischemic HF through activation of RAGE-dependent NF-kB signaling [137]. An HMGB1TLR4 axis is active upon myocardial ischemia/reperfusion injury and the innate immune adaptor MyD88 downstream TLR4 has been shown to mediate neutrophil recruitment and myocardial injury after ischemia-reperfusion in mice. [138]. Matricellular proteins such as tenascin-C and the small leucine-rich proteoglycan biglycan modulate the inflammatory response by binding to TLR2 and/or TLR4 [139, 140]. The matrix component biglycan activates the NLRP3 inflammasome via TLRs and P2X receptors and leads to subsequent IL-1ß release [141]. Other important factors by which HF increases cardiac NLRP3 inflammasome activity are ATP, released when cells die [142], ROS, and mitochondrial DNA. ROS mediates autocrine and paracrine activation and nuclear translocation of NF- $\mathrm{KB}$, which regulates the transcription of pro-IL-1ß and pro-IL-18 [143•]. Mitochondrial DNA released by damaged cells [144] directly primes NLRP3 and ATP via binding to $\mathrm{P} 2 \mathrm{X} 7$ purinergic receptors and leads to potassium efflux, which triggers the assembly of NLRP3 inflammasome. These collective effects result in the activation of NLRP3associated caspase 1 , which processes pro-IL-1ß and pro-IL18 in their mature IL-1ß and IL-18 forms [122]. The abovementioned released cardiac cytokines and other inflammatory mediators not only affect the heart but also different organs as outlined below. Furthermore, several neurohormonal mechanisms that become activated in HF to try and sustain cardiac output in the face of decompensating function [145, 146] also affect inflammation in different organs.

\section{Heart Failure Induces Monocytopoiesis in the Bone Marrow and Spleen}

Monocytes arise from hematopoietic stem cells in the bone marrow, pass through several intermediate progenitor stages (from granulocyte $\mathrm{M} \Phi$ progenitor to $\mathrm{M} \Phi$ dendritic cell progenitor) [147], and emigrate from the bone marrow into the blood pool mediated by the chemokine receptor CCR2 [148]. IL-1 1 released upon MI induces leukopoiesis in the bone marrow and at extramedullary sites $[128,149]$. The relevance of IL-1ß in this process follows from MI mice lacking the IL-1R which exhibits an impaired splenic monocytopoiesis as indicated by a reduced number of colony-forming units, less $M \Phi$ dendritic cell progenitors, and proliferating monocytes in the spleen [149]. The reduced CD45.2+ progeny in the spleen following adoptive transfer of IL-1 $\mathrm{R}^{-/-}$compared to wildtype granulocyte $M \Phi$ progenitors indicates that direct IL-1 signaling on myeloid progenitors controls splenic monocytopoiesis. Sager et al. [128] further demonstrated that anti-IL- $1 \beta$ treatment dampens the post MI increase in hematopoietic stem cell proliferation in the bone marrow. Finally, HF-associated activation of the RAAS also boosts the release of monocytes from their splenic reservoir [97]. The increased monocytopoiesis post MI accelerates coronary plaque growth after the first MI [150] and may be responsible for the high secondary event rates [151].

\section{Heart Failure Provokes Inflammation in the Skeletal Muscle}

It is well established that HF is associated with skeletal muscle wasting and cachexia including increased degradation of myofibrils, myocyte apoptosis, and metabolic imbalance [152]. Less known is the evidence from experimental [153] and patient [154] studies which indicate that HF-elevated serum cytokine levels (most notably TNF- $\alpha$ ) are associated with increased local inflammation in the skeletal muscle. The TNF- $\alpha / \mathrm{IL}-10$ and IL-6/IL-10 ratio is higher in the soleus muscle of rats with HF compared to that of controls [155]. The skeletal muscle of patients with chronic HF with only mildly elevated serum cytokines exhibits increased expression of TNF- $\alpha$, IL-1ß, IL-6, and iNOS compared 
to skeletal muscle of the control patients [154]. This occurs in the absence of infiltrating monocytes or M $\Phi$ s indicating that skeletal myocytes may produce cytokines in a paracrine/autocrine fashion [156]. Furthermore, HF-associated inflammation induces resistance to the anti-inflammatory adipokine adiponectin in the muscle [157]. Interestingly, a recent study demonstrated an increase in markers of muscle atrophy, oxidative stress, and mitochondrial impairments solely in the soleus muscle of HFrEF, but not of HFpEF rats. The authors concluded that this disparity may be mediated, in part, by the different circulating inflammatory cytokines that were elevated between HFpEF and HFrEF, i.e., TNF- $\alpha$ plasma concentrations were significantly increased in HFrEF, whereas IL-1 $\beta$ and IL-12 were higher in HFpEF rats [158]. Unfortunately, the analysis of potential differences in skeletal muscle inflammation between HFpEF and HFrEF rats was beyond the scope of this study. Besides inflammation, HFassociated neurohumoral activation triggers inflammation in the skeletal muscle. Chronic sympathetic stimulation in HF promotes redistribution of blood flow to skeletal muscles through chronic vasoconstriction [152]. Chronic underperfusion of the capillary bed, in turn, promotes skeletal muscle ischemia, which leads to the generation of ROS and muscle inflammation [159]. Furthermore, increased levels of Ang II associated with HF result in impaired vasodilation and aggravate bradykinin degradation, leading to muscle hypoxia and reduced endurance capacity [160]. Gielen et al. [154] described that a 6-month program of regular physical exercise significantly reduced the local expression of TNF- $\alpha$, IL-1ß, IL-6, iNOS, and nitrotyrosine levels in the skeletal muscle of patients with stable moderate chronic systolic HF, while serum cytokine levels remained virtually unchanged. The lower total peripheral resistance after training [161] may contribute to lower oxidative stress and inflammation in the skeletal muscle.

\section{Heart Failure Affects Inflammation in Adipose Tissue}

Pro-inflammatory cytokines are known to reduce the expression of the anti-inflammatory adipokine adiponectin in cultured adipocytes [162] and adiponectin expression in adipose tissue and circulating adiponectin levels are decreased in experimental severe inflammation [163]. However, in humans, adiponectin regulation is complex. Atherosclerosis-related low-grade inflammation has been associated with decreased plasma adiponectin [164], whereas advanced, chronic inflammation with increased adiponectin levels [165]. Antonopoulos et al. [166] demonstrated how the reciprocal effects of systemic inflammation and brain natriuretic peptide (BNP) influence adiponectin expression in patients with HF. Low-grade inflammation reduces the adiponectin levels in populations without significant cardiovascular disease and low plasma BNP, explaining why its low levels predict the onset of cardiovascular disease [167]. However, after the development of advanced cardiovascular disease, the adiponectin levels are no longer negatively controlled by low- grade inflammation, but they are driven upward by circulating BNP levels [168]. Therefore, high circulating adiponectin predicts (indirectly) worse clinical outcome in patients with HF. Therefore, the interpretation of adiponectin as a biomarker should always take into account the underlying cardiovascular disease state [166]. Valero-Munoz et al. [169] recently demonstrated increased neutrophil content in white adipose tissue of HFpEF patients compared to controls. Neutrophils are recognized as primary effector cells in acute inflammatory responses and are implicated in the modulation of adipose tissue inflammation in the early stages of obesity, but their presence in adipose tissue in response to a high-fat diet may last $\leq 90$ days [170]. Therefore, the increased neutrophil presence in white adipose tissue of HFpEF patients suggests the onset of immune activation, setting the stage for tissue infiltration by other immune cells, such as MФs [169].

\section{Heart Failure Increases Gut Permeability and Subsequent Systemic Inflammation}

HF-associated decreased cardiac output, elevated systemic congestion, and distribution of systemic circulation can lead to a decrease in intestinal perfusion and mucosal ischemia and ultimately a disrupted intestinal mucosa. This disruption can in turn lead to increased gut permeability and subsequent enhanced translocation of bacteria and bacterial toxins in the blood, which can contribute to systemic inflammation and further to HF exacerbations [171]. The HF-associated gut luminal hypoxia and decrease in mucosal $\mathrm{pH}$ [172], well known activators of bacterial virulence in microbiota, can also change the microbiota to pathogenic microbiota which further contributes to the raise in gut permeability. A recent study in fact demonstrated that patients with chronic HF have intestinal overgrowth of pathogenic bacteria and Candida species and showed that the increased intestinal permeability correlated with systemic inflammation [173]. Beyond their effect on systemic inflammation, the lowlevel leakage of bacterial products could augment local inflammation of the plaque in vessels, promoting atherogenesis. This is an example of how sites of tissue injury and ischemic damage beyond the myocardium can elicit an "echo" at the level of the atherosclerotic plaque and induce a remote inflammatory response $[7 \cdot \bullet$. This further explains how patients with a primary MI have a higher prevalence to get recurrent ACSs [151].

\section{Heart Failure Affects Neurohumoral System-Dependent Inflammation and Monocytopoiesis}

Pro- and anti-inflammatory cytokine production is regulated by the adrenergic nervous system. Previous studies have demonstrated that $\beta 2$-, but not $\beta 1$-receptor agonists attenuate TNF- $\alpha$ expression, while increasing anti-inflammatory IL10 production [174]. Conversely, $\alpha 1,2$-adrenergic stimulation results in increased expression of TNF- $\alpha$ and reduction in IL- 
10 [175]. Under normal physiologic conditions, norepinephrine, an $\alpha$ - and $\beta$-agonist, reduces TNF- $\alpha$ and enhances IL-10 expression in monocytes exposed to LPS and other stimuli [176]. However, in HF, a paradox exists as both catecholamines and TNF- $\alpha$ are elevated [174]. Ngu et al. [174] recently demonstrated that the norepinephrine regulation of monocyte inflammatory cytokine balance is impaired in HF. The inhibitory effect of noradrenaline on TNF- $\alpha$ production of monocytes from HF patients was lower compared to that of monocytes from control patients, whereas the increase in IL10 production by noradrenaline was also attenuated in HF monocytes. Another example how HF affects the adrenergic nervous system and inflammation is the $B 3$-adrenergic-stimulated activation of bone marrow progenitor cells following MI. The pain and acute stress of the acute MI promotes local catecholamine synthesis in the bone marrow and the systemic release of B3-adrenergic stimulants [7••, 94] The relevance of adrenergic signaling in monocytopoiesis in ischemic disease follows from findings showing that patients undergoing ACS who were non-randomly allocated to $ß$-blocker use before the ACS had significantly lower leukocyte and monocyte counts than those who had never used B-blockers [7••, 94]. Finally, HF activates the RAAS, which also triggers monocytopoiesis as outlined before [97].

\section{Conclusions and Perspectives}

Inflammation and HF are strongly interconnected and mutually reinforce each other. This indicates the difficulty to counteract inflammation and HF once this chronic vicious circle has started and points out the need to control the inflammatory process at an early stage avoiding chronic inflammation and HF. The relevance of the $\beta$-adrenergic system in HF as well as in the control of inflammation (inflammatory reflex versus $\beta 3$ agonism-induced monocytopoiesis) warrants further investigation. The diversity of inflammation further addresses the need for a tailored characterization of inflammation enabling differentiation of inflammation and subsequent target-specific strategies. This necessity is supported by the disappointing results of anti-inflammatory strategies used in HF patients so far $[14,15]$. The characterization and differentiation of inflammation will allow classification of patients in subclasses to provide appropriate treatment. Such a differentiated approach is in line with the growing appreciation and ongoing introduction of precision medicine in cardiology [177], a field of medicine which is a common practice in oncology [178]. It is expected that the characterization of the systemic and/or cardiac immune profile will be part of precision medicine in the future of cardiology. The questions at this stage rise how long this will still take, which methods will be used to that end, and which novel therapeutic targets will be defined.
Acknowledgements This study is supported by the DZHK to SVL and CT and by the Friede Springer Herz Stiftung and Dr. Marija Orlovic Stiftung to SVL.

\section{Compliance with Ethical Standards}

Conflict of Interest Sophie Van Linthout and Carsten Tschöpe declare no conflicts of interest.

Human and Animal Rights and Informed Consent This article does not contain any studies with human or animal subjects performed by any of the authors.

Open Access This article is distributed under the terms of the Creative Commons Attribution 4.0 International License (http:// creativecommons.org/licenses/by/4.0/), which permits unrestricted use, distribution, and reproduction in any medium, provided you give appropriate credit to the original author(s) and the source, provide a link to the Creative Commons license, and indicate if changes were made.

\section{References}

Papers of particular interest, published recently, have been highlighted as:

- Of importance

•• Of major importance

1. Ponikowski P, Voors AA, Anker SD, Bueno H, Cleland JG, Coats AJ, et al., M. Authors/Task Force, R. Document. ESC guidelines for the diagnosis and treatment of acute and chronic heart failure: the task force for the diagnosis and treatment of acute and chronic heart failure of the European Society of Cardiology (ESC). Developed with the special contribution of the Heart Failure Association (HFA) of the ESC. Eur J Heart Fail. 2016;2016(18): 891-975.

2. Borlaug BA, Paulus WJ. Heart failure with preserved ejection fraction: pathophysiology, diagnosis, and treatment. Eur Heart J. 2011;32:670-9.

3. Packer M. The neurohormonal hypothesis: a theory to explain the mechanism of disease progression in heart failure. J Am Coll Cardiol. 1992;20:248-54.

4. Seta Y, Shan K, Bozkurt B, Oral H, Mann DL. Basic mechanisms in heart failure: the cytokine hypothesis. J Card Fail. 1996;2:243-9.

5. Westermann D, Lindner D, Kasner M, Zietsch C, Savvatis K, Escher F, et al. Cardiac inflammation contributes to changes in the extracellular matrix in patients with heart failure and normal ejection fraction. Circ Heart Fail. 2011;4:44-52.

6. Paulus WJ, Tschope C. A novel paradigm for heart failure with preserved ejection fraction: comorbidities drive myocardial dysfunction and remodeling through coronary microvascular endothelial inflammation. J Am Coll Cardiol. 2013;62:263-71. This novel paradigm postulated for heart failure with preserved ejection fraction (HFpEF) proposes a central role for endothelial inflammation induced by comorbidities in HFpEFassociated cardiac remodeling.

7.• Libby P, Nahrendorf M, Swirski FK. Leukocytes link local and systemic inflammation in ischemic cardiovascular disease: an expanded "cardiovascular continuum". J Am Coll Cardiol. 2016;67: 1091-103. This review provides new insights into the 
integrative biology of inflammation as it contributes to ischemic cardiovascular disease, including unsuspected inflammatory signaling networks that link the brain, autonomic nervous system, bone marrow, and spleen to the atherosclerotic plaque and to the infarcting myocardium.

8. Dick SA, Epelman S. Chronic heart failure and inflammation: what do we really know? Circ Res. 2016;119:159-76.

9. Heymans S, Hirsch E, Anker SD, Aukrust P, Balligand JL, CohenTervaert JW, et al. Inflammation as a therapeutic target in heart failure? A scientific statement from the Translational Research Committee of the Heart Failure Association of the European Society of Cardiology. Eur J Heart Fail. 2009;11:119-29.

10. Ridker PM, Luscher TF. Anti-inflammatory therapies for cardiovascular disease. Eur Heart J. 2014;35:1782-91.

11. Torre-Amione G, Kapadia S, Lee J, Durand JB, Bies RD, Young $\mathrm{JB}$, et al. Tumor necrosis factor-alpha and tumor necrosis factor receptors in the failing human heart. Circulation. 1996;93:704-11.

12. Vasan RS, Sullivan LM, Roubenoff R, Dinarello CA, Harris T, Benjamin EJ, et al. Inflammatory markers and risk of heart failure in elderly subjects without prior myocardial infarction: the Framingham Heart Study. Circulation. 2003;107:1486-91.

13. Edelmann F, Holzendorf V, Wachter R, Nolte K, Schmidt AG, Kraigher-Krainer E, et al. Galectin-3 in patients with heart failure with preserved ejection fraction: results from the Aldo-DHF trial. Eur J Heart Fail. 2015;17:214-23.

14. Bozkurt B, Torre-Amione G, Warren MS, Whitmore J, Soran OZ, Feldman AM, et al. Results of targeted anti-tumor necrosis factor therapy with etanercept (ENBREL) in patients with advanced heart failure. Circulation. 2001;103:1044-7.

15. Anker SD, Coats AJ. How to recover from renaissance? The significance of the results of recover, renaissance, renewal and attach. Int J Cardiol. 2002;86:123-30.

16. Medzhitov R. Inflammation 2010: new adventures of an old flame. Cell. 2010;140:771-6.

17. G. Majno, I. Joris, Cells, Tissues, and Disease., Second Edition ed., Oxford University Press 2004.

18. Chen GY, Nunez G. Sterile inflammation: sensing and reacting to damage. Nat Rev Immunol. 2010;10:826-37.

19. J.S. Bezbradica, R.C. Coll, K. Schroder, Sterile signals generate weaker and delayed macrophage NLRP3 inflammasome responses relative to microbial signals, Cell Mol Immunol, (2016).

20. Medzhitov R. Origin and physiological roles of inflammation. Nature. 2008;454:428-35.

21. Hotamisligil GS. Inflammation and metabolic disorders. Nature. 2006;444:860-7.

22. Franks PW, McCarthy MI. Exposing the exposures responsible for type 2 diabetes and obesity. Science. 2016;354:69-73.

23. Lindner D, Zietsch C, Tank J, Sossalla S, Fluschnik N, Hinrichs S, et al. Cardiac fibroblasts support cardiac inflammation in heart failure. Basic Res Cardiol. 2014;109:428.

24. Van Linthout S, Miteva K, Tschope C. Crosstalk between fibroblasts and inflammatory cells. Cardiovasc Res. 2014;102:258-69.

25. Sandanger O, Ranheim T, Vinge LE, Bliksoen M, Alfsnes K, Finsen AV, et al. The NLRP3 inflammasome is up-regulated in cardiac fibroblasts and mediates myocardial ischaemiareperfusion injury. Cardiovasc Res. 2013;99:164-74.

26. Lumeng CN, Saltiel AR. Inflammatory links between obesity and metabolic disease. J Clin Invest. 2011;121:2111-7.

27. Tall AR, Yvan-Charvet L. Cholesterol, inflammation and innate immunity. Nat Rev Immunol. 2015;15:104-16.

28. Spillmann F, Van Linthout S, Miteva K, Lorenz M, Stangl V, Schultheiss HP, et al. LXR agonism improves TNF-alphainduced endothelial dysfunction in the absence of its cholesterolmodulating effects. Atherosclerosis. 2014;232:1-9.
29. Spillmann F, Miteva K, Pieske B, Tschope C, Van Linthout S. High-density lipoproteins reduce endothelial-to-mesenchymal transition. Arterioscler Thromb Vasc Biol. 2015;35:1774-7.

30. Spillmann F, De Geest B, Muthuramu I, Amin R, Miteva K, Pieske B, et al. Apolipoprotein A-I gene transfer exerts immunomodulatory effects and reduces vascular inflammation and fibrosis in ob/ob mice. J Inflamm (Lond). 2016;13:25.

31. Van Linthout S, Spillmann F, Lorenz M, Meloni M, Jacobs F, Egorova M, et al. Vascular-protective effects of high-density lipoprotein include the downregulation of the angiotensin II type 1 receptor. Hypertension. 2009;53:682-7.

32. Libby P, Hansson GK. Inflammation and immunity in diseases of the arterial tree: players and layers. Circ Res. 2015;116:307-11.

33. Odeberg J, Freitag M, Forssell H, Vaara I, Persson ML, Odeberg $\mathrm{H}$, et al. Influence of pre-existing inflammation on the outcome of acute coronary syndrome: a cross-sectional study. BMJ Open. 2016;6:e009968.

34. Kindermann I, Kindermann M, Kandolf R, Klingel K, Bultmann B, Muller T, et al. Predictors of outcome in patients with suspected myocarditis. Circulation. 2008;118:639-48.

35. Berg KE, Ljungcrantz I, Andersson L, Bryngelsson C, Hedblad B, Fredrikson GN, et al. Elevated CD14++ CD16- monocytes predict cardiovascular events. Circ Cardiovasc Genet. 2012;5:122-31.

36. Emami H, Singh P, MacNabb M, Vucic E, Lavender Z, Rudd JHF, et al. Splenic metabolic activity predicts risk of future cardiovascular events demonstration of a cardiosplenic axis in humans. JACC: CARDIOVASCULAR IMAGING; 2015.

37. Biasucci LM, Liuzzo G, Grillo RL, Caligiuri G, Rebuzzi AG, Buffon A, et al. Elevated levels of C-reactive protein at discharge in patients with unstable angina predict recurrent instability. Circulation. 1999;99:855-60.

38. Torre-Amione G, Kapadia S, Benedict C, Oral H, Young JB, Mann DL. Proinflammatory cytokine levels in patients with depressed left ventricular ejection fraction: a report from the Studies of Left Ventricular Dysfunction (SOLVD). J Am Coll Cardiol. 1996;27:1201-6.

39. Deswal A, Petersen NJ, Feldman AM, Young JB, White BG, Mann DL. Cytokines and cytokine receptors in advanced heart failure: an analysis of the cytokine database from the Vesnarinone trial (VEST). Circulation. 2001;103:2055-9.

40. Savvatis K, Pappritz K, Becher PM, Lindner D, Zietsch C, Volk $\mathrm{HD}$, et al. Interleukin-23 deficiency leads to impaired wound healing and adverse prognosis after myocardial infarction. Circ Heart Fail. 2014;7:161-71.

41. Riad A, Jager S, Sobirey M, Escher F, Yaulema-Riss A, Westermann D, et al. Toll-like receptor-4 modulates survival by induction of left ventricular remodeling after myocardial infarction in mice. J Immunol. 2008;180:6954-61.

42. Riad A, Westermann D, Zietsch C, Savvatis K, Becher PM, Bereswill S, et al. TRIF is a critical survival factor in viral cardiomyopathy. J Immunol. 2011;186:2561-70.

43. Kubota T, McTiernan CF, Frye CS, Slawson SE, Lemster BH, Koretsky AP, et al. Dilated cardiomyopathy in transgenic mice with cardiac-specific overexpression of tumor necrosis factor-alpha. Circ Res. 1997;81:627-35.

44. Westermann D, Van Linthout S, Dhayat S, Dhayat N, Schmidt A, Noutsias $\mathrm{M}$, et al. Tumor necrosis factor-alpha antagonism protects from myocardial inflammation and fibrosis in experimental diabetic cardiomyopathy. Basic Res Cardiol. 2007;102:500-7.

45. Savvatis K, Muller I, Frohlich M, Pappritz K, Zietsch C, Hamdani $\mathrm{N}$, et al. Interleukin-6 receptor inhibition modulates the immune reaction and restores titin phosphorylation in experimental myocarditis. Basic Res Cardiol. 2014;109:449.

46. Westermann D, Van Linthout S, Dhayat S, Dhayat N, Escher F, Bucker-Gartner C, et al. Cardioprotective and anti-inflammatory 
effects of interleukin converting enzyme inhibition in experimental diabetic cardiomyopathy. Diabetes. 2007;56:1834-41.

47. Koch M, Savvatis K, Scheeler M, Dhayat S, Bonaventura K, Pohl $\mathrm{T}$, et al. Immunosuppression with an interleukin-2 fusion protein leads to improved LV function in experimental ischemic cardiomyopathy. Int Immunopharmacol. 2010;10:207-12.

48. Leuschner F, Courties G, Dutta P, Mortensen LJ, Gorbatov R, Sena B, et al. Silencing of CCR2 in myocarditis. Eur Heart J. 2015;36:1478-88.

49. Van Linthout S, Riad A, Dhayat N, Spillmann F, Du J, Dhayat S, et al. Anti-inflammatory effects of atorvastatin improve left ventricular function in experimental diabetic cardiomyopathy. Diabetologia. 2007;50:1977-86.

50. Van Linthout S, Spillmann F, Riad A, Trimpert C, Lievens J, Meloni M, et al. Human apolipoprotein AI gene transfer reduces the development of experimental diabetic cardiomyopathy. Circulation. 2008;117:1563-73.

51. Van Linthout S, Spillmann F, Graiani G, Miteva K, Peng J, Van Craeyveld E, et al. Down-regulation of endothelial TLR4 signalling after apo AI gene transfer contributes to improved survival in an experimental model of lipopolysaccharide-induced inflammation. J Mol Med (Berl). 2011;89:151-60.

52. Van Linthout S, Savvatis K, Miteva K, Peng J, Ringe J, Warstat K, et al. Mesenchymal stem cells improve murine acute coxsackievirus B3-induced myocarditis. Eur Heart J. 2011;32: 2168-78.

53. Savvatis K, van Linthout S, Miteva K, Pappritz K, Westermann D, Schefold JC, et al. Mesenchymal stromal cells but not cardiac fibroblasts exert beneficial systemic immunomodulatory effects in experimental myocarditis. PLoS One. 2012;7:e41047.

54. K. Miteva, K. Pappritz, M. El-Shafeey, F. Dong, J. Ringe, C. Tschope, S. Van Linthout, Mesenchymal stromal cells modulate monocytes trafficking in Coxsackievirus B3-induced myocarditis, Stem Cells Transl Med, 2017.

55. Miteva K, Haag M, Peng J, Savvatis K, Becher PM, Seifert M, et al. Human cardiac-derived adherent proliferating cells reduce murine acute Coxsackievirus B3-induced myocarditis. PLoS One. 2011;6:e28513.

56. Miteva K, Van Linthout S, Pappritz K, Muller I, Spillmann F, Haag M, et al. Human endomyocardial biopsy specimen-derived stromal cells modulate angiotensin II-induced cardiac remodeling. Stem Cells Transl Med. 2016;5:1707-18.

57. Wu CK, Lee JK, Chiang FT, Yang CH, Huang SW, Hwang JJ, et al. Plasma levels of tumor necrosis factor-alpha and interleukin6 are associated with diastolic heart failure through downregulation of sarcoplasmic reticulum $\mathrm{Ca} 2+$ ATPase. Crit Care Med. 2011;39:984-92.

58. Thaik CM, Calderone A, Takahashi N, Colucci WS. Interleukin-1 beta modulates the growth and phenotype of neonatal rat cardiac myocytes. J Clin Invest. 1995;96:1093-9.

59. Yokoyama T, Vaca L, Rossen RD, Durante W, Hazarika P, Mann DL. Cellular basis for the negative inotropic effects of tumor necrosis factor-alpha in the adult mammalian heart. J Clin Invest. 1993;92:2303-12.

60. Sedej S, Schmidt A, Denegri M, Walther S, Matovina M, Arnstein $\mathrm{G}$, et al. Subclinical abnormalities in sarcoplasmic reticulum $\mathrm{Ca}(2+)$ release promote eccentric myocardial remodeling and pump failure death in response to pressure overload. J Am Coll Cardiol. 2014;63:1569-79.

61. Tschope C, Lam CS. Diastolic heart failure: what we still don't know. Looking for new concepts, diagnostic approaches, and the role of comorbidities. Herz. 2012;37:875-9.

62. Yokoyama T, Nakano M, Bednarczyk JL, McIntyre BW, Entman M, Mann DL. Tumor necrosis factor-alpha provokes a hypertrophic growth response in adult cardiac myocytes. Circulation. 1997;95:1247-52.
63. Condorelli G, Morisco C, Latronico MV, Claudio PP, Dent P, Tsichlis $\mathrm{P}$, et al. TNF-alpha signal transduction in rat neonatal cardiac myocytes: definition of pathways generating from the TNF-alpha receptor. FASEB J. 2002;16:1732-7.

64. Takahashi M. NLRP3 inflammasome as a novel player in myocardial infarction. Int Heart J. 2014;55:101-5.

65. Gurantz D, Cowling RT, Varki N, Frikovsky E, Moore CD, Greenberg BH. IL-1beta and TNF-alpha upregulate angiotensin II type 1 (AT1) receptors on cardiac fibroblasts and are associated with increased AT1 density in the post-MI heart. J Mol Cell Cardiol. 2005;38:505-15.

66. Peng J, Gurantz D, Tran V, Cowling RT, Greenberg BH. Tumor necrosis factor-alpha-induced AT1 receptor upregulation enhances angiotensin II-mediated cardiac fibroblast responses that favor fibrosis. Circ Res. 2002;91:1119-26.

67. Wang Y, Li Y, Wu Y, Jia L, Wang J, Xie B, et al. 5TNF-alpha and IL-1 beta neutralization ameliorates angiotensin II-induced cardiac damage in male mice. Endocrinology. 2014;155:2677-87.

68. Sullivan DE, Ferris M, Nguyen H, Abboud E, Brody AR. TNFalpha induces TGF-betal expression in lung fibroblasts at the transcriptional level via AP-1 activation. J Cell Mol Med. 2009;13:1866-76.

69. Voloshenyuk TG, Hart AD, Khoutorova E, Gardner JD. TNFalpha increases cardiac fibroblast lysyl oxidase expression through TGF-beta and PI3Kinase signaling pathways. Biochem Biophys Res Commun. 2011;413:370-5.

70. Yokoyama C, Aoyama T, Ido T, Kakino A, Shiraki T, Tanaka T, et al. Deletion of LOX-1 protects against heart failure induced by doxorubicin. PLoS One. 2016;11:e0154994.

71. Yang J, Savvatis K, Kang JS, Fan P, Zhong H, Schwartz K, et al. Targeting LOXL2 for cardiac interstitial fibrosis and heart failure treatment. Nat Commun. 2016;7:13710.

72. C. Humeres, R. Vivar, P. Boza, C. Munoz, S. Bolivar, R. Anfossi, J.M. Osorio, F. Olivares-Silva, L. Garcia, G. Diaz-Araya, Cardiac fibroblast cytokine profiles induced by proinflammatory or profibrotic stimuli promote monocyte recruitment and modulate macrophage M1/M2 balance in vitro, J Mol Cell Cardiol, 2016.

73. Tschope C, Van Linthout S. New insights in (inter)cellular mechanisms by heart failure with preserved ejection fraction. Curr Heart Fail Rep. 2014;11:436-44.

74. Bang C, Antoniades C, Antonopoulos AS, Eriksson U, Franssen $\mathrm{C}$, Hamdani $\mathrm{N}$, et al. Intercellular communication lessons in heart failure. Eur J Heart Fail. 2015;17:1091-103.

75. Tamaru M, Tomura K, Sakamoto S, Tezuka K, Tamatani T, Narumi S. Interleukin-1beta induces tissue- and cell typespecific expression of adhesion molecules in vivo. Arterioscler Thromb Vasc Biol. 1998;18:1292-303.

76. Zakrzewicz A, Grafe M, Terbeek D, Bongrazio M, Auch-Schwelk $\mathrm{W}$, Walzog B, et al. L-selectin-dependent leukocyte adhesion to microvascular but not to macrovascular endothelial cells of the human coronary system. Blood. 1997;89:3228-35.

77. Woodfin A, Voisin MB, Imhof BA, Dejana E, Engelhardt B, Nourshargh S. Endothelial cell activation leads to neutrophil transmigration as supported by the sequential roles of ICAM-2, JAMA, and PECAM-1. Blood. 2009;113:6246-57.

78. Chandrasekar B, Vemula K, Surabhi RM, Li-Weber M, OwenSchaub LB, Jensen LE, et al. Activation of intrinsic and extrinsic proapoptotic signaling pathways in interleukin-18-mediated human cardiac endothelial cell death. J Biol Chem. 2004;279: 20221-33.

79. Okada H, Woodcock-Mitchell J, Mitchell J, Sakamoto T, Marutsuka K, Sobel BE, et al. Induction of plasminogen activator inhibitor type 1 and type 1 collagen expression in rat cardiac microvascular endothelial cells by interleukin-1 and its dependence on oxygen-centered free radicals. Circulation. 1998;97: 2175-82. 
80. Zeisberg EM, Tarnavski O, Zeisberg M, Dorfman AL, McMullen JR, Gustafsson E, et al. Endothelial-to-mesenchymal transition contributes to cardiac fibrosis. Nat Med. 2007;13:952-61.

81. Chen W, Spitzl A, Mathes D, Nikolaev VO, Werner F, Weirather J, et al. Endothelial actions of ANP enhance myocardial inflammatory infiltration in the early phase after acute infarction. Circ Res. 2016;119:237-48.

82. $\mathrm{Hu}$ YF, Chen YJ, Lin YJ, Chen SA. Inflammation and the pathogenesis of atrial fibrillation. Nat Rev Cardiol. 2015;12:230-43.

83. Shimano M, Ouchi N, Walsh K. Cardiokines: recent progress in elucidating the cardiac secretome. Circulation. 2012;126:e327-32.

84. Kapadia S, Lee J, Torre-Amione G, Birdsall HH, Ma TS, Mann DL. Tumor necrosis factor-alpha gene and protein expression in adult feline myocardium after endotoxin administration. J Clin Invest. 1995;96:1042-52.

85. Liu Y, Lian K, Zhang L, Wang R, Yi F, Gao C, et al. TXNIP mediates NLRP3 inflammasome activation in cardiac microvascular endothelial cells as a novel mechanism in myocardial ischemia/reperfusion injury. Basic Res Cardiol. 2014;109:415.

86. Pinto AR, Ilinykh A, Ivey MJ, Kuwabara JT, D'Antoni ML, Debuque R, et al. Revisiting cardiac cellular composition. Circ Res. 2016;118:400-9.

87. Torre-Amione G, Kapadia S, Lee J, Bies RD, Lebovitz R, Mann DL. Expression and functional significance of tumor necrosis factor receptors in human myocardium. Circulation. 1995;92: 1487-93.

88. Toldo S, Kannan H, Bussani R, Anzini M, Sonnino C, Sinagra G, et al. Formation of the inflammasome in acute myocarditis. Int $\mathrm{J}$ Cardiol. 2014;171:e119-21.

89. Sager HB, Hulsmans M, Lavine KJ, Moreira MB, Heidt T, Courties G, et al. Proliferation and recruitment contribute to myocardial macrophage expansion in chronic heart failure. Circ Res. 2016;119:853-64.

90. Frantz S, Nahrendorf M. Cardiac macrophages and their role in ischaemic heart disease. Cardiovasc Res. 2014;102:240-8.

91. Italiani P, Boraschi D. From monocytes to M1/M2 macrophages: phenotypical vs. functional differentiation. Front Immunol. 2014;5:514.

92. Courties G, Heidt T, Sebas M, Iwamoto Y, Jeon D, Truelove J, et al. In vivo silencing of the transcription factor IRF5 reprograms the macrophage phenotype and improves infarct healing. J Am Coll Cardiol. 2014;63:1556-66.

93. Kim EJ, Kim S, Kang DO, Seo HS. Metabolic activity of the spleen and bone marrow in patients with acute myocardial infarction evaluated by $18 \mathrm{f}$-fluorodeoxyglucose positron emission tomograpic imaging. Circ Cardiovasc Imaging. 2014;7:454-60.

94. Dutta P, Courties G, Wei Y, Leuschner F, Gorbatov R, Robbins $\mathrm{CS}$, et al. Myocardial infarction accelerates atherosclerosis. Nature. 2012;487:325-9.

95. Swirski FK, Nahrendorf M, Etzrodt M, Wildgruber M, CortezRetamozo V, Panizzi P, et al. Identification of splenic reservoir monocytes and their deployment to inflammatory sites. Science. 2009;325:612-6.

96. Ismahil MA, Hamid T, Bansal SS, Patel B, Kingery JR, Prabhu SD. Remodeling of the mononuclear phagocyte network underlies chronic inflammation and disease progression in heart failure: critical importance of the cardiosplenic axis. Circ Res. 2014;114:266-82.

97. Leuschner F, Panizzi P, Chico-Calero I, Lee WW, Ueno T, CortezRetamozo V, et al. Angiotensin-converting enzyme inhibition prevents the release of monocytes from their splenic reservoir in mice with myocardial infarction. Circ Res. 2010:1364-73.

98. van der Laan AM, Ter Horst EN, Delewi R, Begieneman MP, Krijnen PA, Hirsch A, et al. Monocyte subset accumulation in the human heart following acute myocardial infarction and the role of the spleen as monocyte reservoir. Eur Heart J. 2014;35: 376-85.

99. Tsujioka H, Imanishi T, Ikejima H, Kuroi A, Takarada S, Tanimoto T, et al. Impact of heterogeneity of human peripheral blood monocyte subsets on myocardial salvage in patients with primary acute myocardial infarction. J Am Coll Cardiol. 2009;54:130-8.

100. Klingenberg R, Luscher TF. Rheumatoid arthritis and coronary atherosclerosis: two cousins engaging in a dangerous liaison. Eur Heart J. 2015;36:3423-5.

101. Mason JC, Libby P. Cardiovascular disease in patients with chronic inflammation: mechanisms underlying premature cardiovascular events in rheumatologic conditions. Eur Heart J. 2015;36:482-489c.

102. Elenkov IJ, Wilder RL, Chrousos GP, Vizi ES. The sympathetic nerve-an integrative interface between two supersystems: the brain and the immune system. Pharmacol Rev. 2000;52:595-638.

103. Ahlehoff O, Gislason GH, Jorgensen CH, Lindhardsen J, Charlot $\mathrm{M}$, Olesen JB, et al. Psoriasis and risk of atrial fibrillation and ischaemic stroke: a Danish Nationwide Cohort Study. Eur Heart J. 2012;33:2054-64.

104. P.E. Lazzerini, P.L. Capecchi, F. Laghi-Pasini, Systemic inflammation and arrhythmic risk: lessons from rheumatoid arthritis, Eur Heart J. 2016.

105. Xu H, Barnes GT, Yang Q, Tan G, Yang D, Chou CJ, et al. Chronic inflammation in fat plays a crucial role in the development of obesity-related insulin resistance. J Clin Invest. 2003;112: 1821-30.

106. Castoldi A, Naffah de Souza C, Camara NO, Moraes-Vieira PM. The macrophage switch in obesity development. Front Immunol. 2015;6:637.

107. Ohashi K, Kihara S, Ouchi N, Kumada M, Fujita K, Hiuge A, et al. Adiponectin replenishment ameliorates obesity-related hypertension. Hypertension. 2006;47:1108-16.

108. Shibata R, Ouchi N, Ito M, Kihara S, Shiojima I, Pimentel DR, et al. Adiponectin-mediated modulation of hypertrophic signals in the heart. Nat Med. 2004;10:1384-9.

109. Shibata R, Sato K, Pimentel DR, Takemura Y, Kihara S, Ohashi K, et al. Adiponectin protects against myocardial ischemiareperfusion injury through AMPK- and COX-2-dependent mechanisms. Nat Med. 2005;11:1096-103.

110. Shibata R, Izumiya Y, Sato K, Papanicolaou K, Kihara S, Colucci WS, et al. Adiponectin protects against the development of systolic dysfunction following myocardial infarction. J Mol Cell Cardiol. 2007;42:1065-74.

111. Sam F, Duhaney TA, Sato K, Wilson RM, Ohashi K, SonoRomanelli S, et al. Adiponectin deficiency, diastolic dysfunction, and diastolic heart failure. Endocrinology. 2010;151:322-31.

112. Tanaka K, Wilson RM, Essick EE, Duffen JL, Scherer PE, Ouchi $\mathrm{N}$, et al. Effects of adiponectin on calcium-handling proteins in heart failure with preserved ejection fraction. Circ Heart Fail. 2014;7:976-85.

113. Nagareddy PR, Murphy AJ, Stirzaker RA, Hu Y, Yu S, Miller RG, et al. Hyperglycemia promotes myelopoiesis and impairs the resolution of atherosclerosis. Cell Metab. 2013;17:695-708.

114. Nagareddy PR, Kraakman M, Masters SL, Stirzaker RA, Gorman DJ, Grant RW, et al. Adipose tissue macrophages promote myelopoiesis and monocytosis in obesity. Cell Metab. 2014;19: 821-35.

115. Franssen C, Chen S, Unger A, Korkmaz HI, De Keulenaer GW, Tschope C, et al. Myocardial microvascular inflammatory endothelial activation in heart failure with preserved ejection fraction. JACC Heart Fail. 2016;4:312-24.

116. Hamdani N, Franssen C, Lourenco A, Falcao-Pires I, Fontoura D, Leite S, et al. Myocardial titin hypophosphorylation importantly 
contributes to heart failure with preserved ejection fraction in a rat metabolic risk model. Circ Heart Fail. 2013;6:1239-49.

117. Hamdani N, Paulus WJ. Myocardial titin and collagen in cardiac diastolic dysfunction: partners in crime. Circulation. 2013;128:5-8.

118. Kasner M, Westermann D, Lopez B, Gaub R, Escher F, Kuhl U, et al. Diastolic tissue Doppler indexes correlate with the degree of collagen expression and cross-linking in heart failure and normal ejection fraction. J Am Coll Cardiol. 2011;57:977-85.

119. Murdoch CE, Chaubey S, Zeng L, Yu B, Ivetic A, Walker SJ, et al. Endothelial NADPH oxidase-2 promotes interstitial cardiac fibrosis and diastolic dysfunction through proinflammatory effects and endothelial-mesenchymal transition. J Am Coll Cardiol. 2014;63: $2734-41$

120. Ogawa K, Hirooka Y, Kishi T, Ide T, Sunagawa K. Partially silencing brain toll-like receptor 4 prevents in part left ventricular remodeling with sympathoinhibition in rats with myocardial infarction-induced heart failure. PLoS One. 2013;8:e69053.

121. Kishi T. Heart failure as a disruption of dynamic circulatory homeostasis mediated by the brain. Int Heart J. 2016;57:145-9.

122. Jahng JW, Song E, Sweeney G. Crosstalk between the heart and peripheral organs in heart failure. Exp Mol Med. 2016;48:e217.

123. Loncar G, Fulster S, von Haehling S, Popovic V. Metabolism and the heart: an overview of muscle, fat, and bone metabolism in heart failure. Int J Cardiol. 2013;162:77-85.

124. Schroer AK, Merryman WD. Mechanobiology of myofibroblast adhesion in fibrotic cardiac disease. J Cell Sci. 2015;128:1865-75.

125. Yoshida T, Friehs I, Mummidi S, del Nido PJ, Addulnour-Nakhoul S, Delafontaine P, et al. Pressure overload induces IL-18 and IL$18 \mathrm{R}$ expression, but markedly suppresses IL-18BP expression in a rabbit model. IL-18 potentiates TNF-alpha-induced cardiomyocyte death. J Mol Cell Cardiol. 2014;75:141-51.

126. Shyu KG, Wang BW, Lin CM, Chang H. Cyclic stretch enhances the expression of toll-like receptor 4 gene in cultured cardiomyocytes via $\mathrm{p} 38$ MAP kinase and NF-kappaB pathway. J Biomed Sci. 2010;17:15

127. Honsho S, Nishikawa S, Amano K, Zen K, Adachi Y, Kishita E, et al. Pressure-mediated hypertrophy and mechanical stretch induces IL-1 release and subsequent IGF-1 generation to maintain compensative hypertrophy by affecting Akt and JNK pathways. Circ Res. 2009;105:1149-58.

128. Sager HB, Heidt T, Hulsmans M, Dutta P, Courties G, Sebas M, et al. Targeting interleukin-1beta reduces leukocyte production after acute myocardial infarction. Circulation. 2015;132:1880-90.

129. Davies PF. Hemodynamic shear stress and the endothelium in cardiovascular pathophysiology. Nat Clin Pract Cardiovasc Med. 2009;6:16-26.

130. McCormick ME, Manduchi E, Witschey WR, Gorman RC, Gorman JH 3rd, Jiang YZ, et al. Spatial phenotyping of the endocardial endothelium as a function of intracardiac hemodynamic shear stress. J Biomech. 2017;50:11-9.

131. Pugin J, Dunn I, Jolliet P, Tassaux D, Magnenat JL, Nicod LP, et al. Activation of human macrophages by mechanical ventilation in vitro. Am J Phys. 1998;275:L1040-50.

132. Sakamoto H, Aikawa M, Hill CC, Weiss D, Taylor WR, Libby P, et al. Biomechanical strain induces class a scavenger receptor expression in human monocyte/macrophages and THP-1 cells: a potential mechanism of increased atherosclerosis in hypertension. Circulation. 2001;104:109-14.

133. Boyd JH, Mathur S, Wang Y, Bateman RM, Walley KR. Toll-like receptor stimulation in cardiomyoctes decreases contractility and initiates an NF-kappaB dependent inflammatory response. Cardiovasc Res. 2006;72:384-93.

134. Bliksoen M, Mariero LH, Torp MK, Baysa A, Ytrehus K, Haugen F, et al. Extracellular mtDNA activates NF-kappaB via toll-like receptor 9 and induces cell death in cardiomyocytes. Basic Res Cardiol. 2016;111:42.

135. Tian J, Guo X, Liu XM, Liu L, Weng QF, Dong SJ, et al. Extracellular HSP60 induces inflammation through activating and up-regulating TLRs in cardiomyocytes. Cardiovasc Res. 2013;98:391-401.

136. Rohde D, Schon C, Boerries M, Didrihsone I, Ritterhoff J, Kubatzky KF, et al. S100A1 is released from ischemic cardiomyocytes and signals myocardial damage via toll-like receptor 4. EMBO Mol Med. 2014;6:778-94.

137. Volz HC, Laohachewin D, Seidel C, Lasitschka F, Keilbach K, Wienbrandt AR, et al. S100A8/A9 aggravates post-ischemic heart failure through activation of RAGE-dependent NF-kappaB signaling. Basic Res Cardiol. 2012;107:250.

138. Feng Y, Zhao H, Xu X, Buys ES, Raher MJ, Bopassa JC, et al. Innate immune adaptor MyD88 mediates neutrophil recruitment and myocardial injury after ischemia-reperfusion in mice. Am J Physiol Heart Circ Physiol. 2008;295:H1311-8.

139. Midwood K, Sacre S, Piccinini AM, Inglis J, Trebaul A, Chan E, et al. Tenascin-C is an endogenous activator of toll-like receptor 4 that is essential for maintaining inflammation in arthritic joint disease. Nat Med. 2009;15:774-80.

140. Nishioka T, Onishi K, Shimojo N, Nagano Y, Matsusaka H, Ikeuchi $\mathrm{M}$, et al. Tenascin-C may aggravate left ventricular remodeling and function after myocardial infarction in mice. Am J Physiol Heart Circ Physiol. 2010;298:H1072-8.

141. Babelova A, Moreth K, Tsalastra-Greul W, Zeng-Brouwers J, Eickelberg O, Young MF, et al. Biglycan, a danger signal that activates the NLRP3 inflammasome via toll-like and P2X receptors. J Biol Chem. 2009;284:24035-48.

142. Franchi L, Eigenbrod T, Nunez G. Cutting edge: TNF-alpha mediates sensitization to ATP and silica via the NLRP3 inflammasome in the absence of microbial stimulation. J Immunol. 2009;183:792-6.

143. Sutterwala FS, Haasken S, Cassel SL. Mechanism of NLRP3 inflammasome activation. Ann N Y Acad Sci. 2014;1319:82-95.

This comprehensive review highlights our current understanding of the mechanisms of both priming and activation of the NLRP3 inflammasome.

144. Zhou R, Yazdi AS, Menu P, Tschopp J. A role for mitochondria in NLRP3 inflammasome activation. Nature. 2011;469:221-5.

145. Lymperopoulos A, Rengo G, Koch WJ. Adrenergic nervous system in heart failure: pathophysiology and therapy. Circ Res. 2013;113:739-53.

146. Pavo N, Wurm R, Goliasch G, Novak JF, Strunk G, Gyongyosi M, et al. Renin-angiotensin system fingerprints of heart failure with reduced ejection fraction. J Am Coll Cardiol. 2016;68:2912-4.

147. Geissmann F, Manz MG, Jung S, Sieweke MH, Merad M, Ley K. Development of monocytes, macrophages, and dendritic cells. Science. 2010;327:656-61.

148. Serbina NV, Pamer EG. Monocyte emigration from bone marrow during bacterial infection requires signals mediated by chemokine receptor CCR2. Nat Immunol. 2006;7:311-7.

149. Leuschner F, Rauch PJ, Ueno T, Gorbatov R, Marinelli B, Lee WW, et al. Rapid monocyte kinetics in acute myocardial infarction are sustained by extramedullary monocytopoiesis. J Exp Med. 2012;209:123-37.

150. Han Y, Jing J, Tu S, Tian F, Xue H, Chen W, et al. ST elevation acute myocardial infarction accelerates non-culprit coronary lesion atherosclerosis. Int J Cardiovasc Imaging. 2014;30:253-61.

151. Nahrendorf M, Swirski FK. Innate immune cells in ischaemic heart disease: does myocardial infarction beget myocardial infarction? Eur Heart J. 2016;37:868-72.

152. Nilsson KR, Duscha BD, Hranitzky PM, Kraus WE. Chronic heart failure and exercise intolerance: the hemodynamic paradox. Curr Cardiol Rev. 2008;4:92-100. 
153. Batista ML Jr, Rosa JC, Lopes RD, Lira FS, Martins E Jr, Yamashita AS, et al. Exercise training changes IL-10/TNF-alpha ratio in the skeletal muscle of post-MI rats. Cytokine. 2010;49: $102-8$.

154. Gielen S, Adams V, Mobius-Winkler S, Linke A, Erbs S, Yu J, et al. Anti-inflammatory effects of exercise training in the skeletal muscle of patients with chronic heart failure. J Am Coll Cardiol. 2003;42:861-8.

155. Rossato DD, Dal Lago P, Hentschke VS, Rucatti AL, Signori LU, Silveira MN, et al. Ultrasound modulates skeletal muscle cytokine levels in rats with heart failure. Ultrasound Med Biol. 2015;41: 797-805.

156. Saghizadeh M, Ong JM, Garvey WT, Henry RR, Kern PA. The expression of TNF alpha by human muscle. Relationship to insulin resistance. J Clin Invest. 1996;97:1111-6.

157. Van Berendoncks AM, Garnier A, Beckers P, Hoymans VY, Possemiers N, Fortin D, et al. Functional adiponectin resistance at the level of the skeletal muscle in mild to moderate chronic heart failure. Circ Heart Fail. 2010;3:185-94.

158. Seiler M, Bowen TS, Rolim N, Dieterlen MT, Werner S, Hoshi T, et al. Skeletal muscle alterations are exacerbated in heart failure with reduced compared with preserved ejection fraction: mediated by circulating cytokines? Circ Heart Fail. 2016;9

159. Tsutsui H, Ide T, Hayashidani S, Suematsu N, Shiomi T, Wen J, et al. Enhanced generation of reactive oxygen species in the limb skeletal muscles from a murine infarct model of heart failure. Circulation. 2001;104:134-6.

160. Clark AL, Poole-Wilson PA, Coats AJ. Exercise limitation in chronic heart failure: central role of the periphery. J Am Coll Cardiol. 1996;28:1092-102.

161. Hambrecht R, Gielen S, Linke A, Fiehn E, Yu J, Walther C, et al. Effects of exercise training on left ventricular function and peripheral resistance in patients with chronic heart failure: a randomized trial. JAMA. 2000;283:3095-101.

162. Wang B, Jenkins JR, Trayhurn P. Expression and secretion of inflammation-related adipokines by human adipocytes differentiated in culture: integrated response to TNF-alpha. Am J Physiol Endocrinol Metab. 2005;288:E731-40.

163. Van Linthout S, Foryst-Ludwig A, Spillmann F, Peng J, Feng Y, Meloni M, et al. Impact of HDL on adipose tissue metabolism and adiponectin expression. Atherosclerosis. 2010;210:438-44.

164. Pilz S, Mangge H, Wellnitz B, Seelhorst U, Winkelmann BR, Tiran B, et al. Adiponectin and mortality in patients undergoing coronary angiography. J Clin Endocrinol Metab. 2006;91:427786.

165. Ozgen M, Koca SS, Dagli N, Balin M, Ustundag B, Isik A. Serum adiponectin and vaspin levels in rheumatoid arthritis. Arch Med Res. 2010;41:457-63.
166. Antonopoulos AS, Margaritis M, Coutinho P, Digby J, Patel R, Psarros C, et al. Reciprocal effects of systemic inflammation and brain natriuretic peptide on adiponectin biosynthesis in adipose tissue of patients with ischemic heart disease. Arterioscler Thromb Vasc Biol. 2014;34:2151-9.

167. Koenig W, Khuseyinova N, Baumert J, Meisinger C, Lowel H. Serum concentrations of adiponectin and risk of type 2 diabetes mellitus and coronary heart disease in apparently healthy middleaged men: results from the 18-year follow-up of a large cohort from southern Germany. J Am Coll Cardiol. 2006;48:1369-77.

168. Tsukamoto O, Fujita M, Kato M, Yamazaki S, Asano Y, Ogai A, et al. Natriuretic peptides enhance the production of adiponectin in human adipocytes and in patients with chronic heart failure. J Am Coll Cardiol. 2009;53:2070-7.

169. Valero-Munoz M, Li S, Wilson RM, Hulsmans M, Aprahamian T, Fuster JJ, et al. Heart failure with preserved ejection fraction induces beiging in adipose tissue. Circ Heart Fail. 2016;9:e002724.

170. Talukdar S, Oh DY, Bandyopadhyay G, Li D, Xu J, McNelis J, et al. Neutrophils mediate insulin resistance in mice fed a high-fat diet through secreted elastase. Nat Med. 2012;18:1407-12.

171. Nagatomo Y, Tang WH. Intersections between microbiome and heart failure: revisiting the gut hypothesis. J Card Fail. 2015;21: 973-80.

172. Krack A, Richartz BM, Gastmann A, Greim K, Lotze U, Anker $\mathrm{SD}$, et al. Studies on intragastric $\mathrm{PCO} 2$ at rest and during exercise as a marker of intestinal perfusion in patients with chronic heart failure. Eur J Heart Fail. 2004;6:403-7.

173. Pasini E, Aquilani R, Testa C, Baiardi P, Angioletti S, Boschi F, et al. Pathogenic gut flora in patients with chronic heart failure. JACC Heart Fail. 2016;4:220-7.

174. Ng TM, Toews ML. Impaired norepinephrine regulation of monocyte inflammatory cytokine balance in heart failure. World $\mathrm{J}$ Cardiol. 2016;8:584-9.

175. Spengler RN, Allen RM, Remick DG, Strieter RM, Kunkel SL. Stimulation of alpha-adrenergic receptor augments the production of macrophage-derived tumor necrosis factor. J Immunol. 1990;145:1430-4.

176. Chelmicka-Schorr E, Kwasniewski MN, Czlonkowska A. Sympathetic nervous system and macrophage function. Ann N Y Acad Sci. 1992;650:40-5.

177. Antman EM, Loscalzo J. Precision medicine in cardiology. Nat Rev Cardiol. 2016;13:591-602.

178. Vargas AJ, Harris CC. Biomarker development in the precision medicine era: lung cancer as a case study. Nat Rev Cancer. 2016;16:525-37. 